\title{
Küçük ve Mikro İşletmeler için Finansal Raporlama Standardı (KÜMİ FRS) Taslağ1 Çerçevesinde Hasılatın Muhasebeleştirilmesi ve Diğer Finansal Raporlama Standartları ile Karş1laştırılması
}

\section{Accounting for Revenue in the Framework of the Draft Financial Reporting Standard for Small and Micro Sized Enterprises and Comparison with Other Financial Reporting Standards}

\author{
Neşegül Parlak ${ }^{1}$ @ \\ ${ }^{1}$ Dr. Öğr. Gör., Ordu Üniversitesi, Fatsa Meslek Yüksek Okulu, Muhasebe ve Vergi Bölümü, Ordu, Türkiye \\ E-posta: nparlak@odu.edu.tr \\ ORCID: N.P. 0000-0002-1669-7389
}

\section{öz}

Türkiye'de işletmelerin finansal raporlarının karşılaştırılabilir, gerçeğe ve ihtiyaca uygun sunumunu sağlamak amacı ile uluslararası düzenlemelere paralel olarak standartlaşmaya gidilmektedir. Bu amaçla, Küçük ve mikro işletmeler için hazırlanan KÜMİ FRS seti taslağı yayımlanmış ve kamuoyunun görüşüne sunulmuştur. KÜMİ FRS Bölüm 7'de hasılat standardına yer verilmiştir. Küçük ve mikro işletmelerin mal satışı ve hizmet sunumuna ilişkin ölçme ve kayıt altına alma işlemlerinin standartta belirtilen ilkeler çerçevesinde yapılması finansal tabloların karşılaştırılabilir olmasını ve işletmenin finansal bilgileri ile ilgilenen tarafların işletmeye ilişkin doğru kararlarlar almalarını sağlayacaktır. Bu çalışmada, KÜMİ FRS Bölüm 7 Hasılat Standardı, mevcut uygulama ve standartlar ile karşılaştırmalı olarak incelenmiştir. KÜMİ FRS Bölüm 7'ye göre hasılatın muhasebeleştirilmesinde özellik arz eden konular örnekler yardımı ile ele alınmıştır.

Anahtar kelimeler: KÜMİ FRS Seti Taslağı Bölüm 7, Küçük ve Mikro İşletme, Hasılat

\section{ABSTRACT}

In Turkey, standardizations are made in accordance with international regulations to ensure that companies prepare and present comparable, factual, and all-purpose financial statements. Thus, a draft of the financial reporting standard (FRS) for Small and Misro Sized Enterprises (SMEs) was published and presented to the public. In this case, the revenue standard is the FRS for SMEs P7. Additionally, conducting this measurement and recording the service encounters and sales of goods based on this framework will not only ensure comparable, factual, and all-purpose financial statements, but it will also help make correct decisions for the parties interested in the financial information of such enterprises. In this study, the FRS for SMEs P7 was analyzed in comparison to the current practices and standards, after which the accounting of revenue within this framework was discussed with examples. Keywords: FRS for SMEs P7, Small and Micro Sized Enterprises, Revenue

Başvuru/Submitted: 20.05.2021 Revizyon Talebi/Revision Requested: 18.06.2021 Son Revizyon/Last Revision Received: 06.07.2021 Kabul/Accepted: 14.07.2021 Sorumlu yazar/Corresponding author: Neşegül Parlak / nparlak@odu.edu.tr

Atıf/Citation: Parlak, N. (2021). Küçük ve mikro işletmeler için finansal raporlama standardı (KÜMİ FRS) taslağı çerçevesinde hasılatın muhasebeleștirilmesi ve diğer finansal raporlama standartları ile karșılaştırılması. Muhasebe Enstitüsü Dergisi - Journal of Accounting Institute, 65 , 75-89. https://doi.org/10.26650/MED.939802 


\section{Extended Abstract}

In general, financial statement users exploit an enterprise's financial statements to evaluate its performance and make future investment plans. This information produced by the enterprise's accounting information system and contained in the financial statements must be understandable, factual, all-purpose, reliable, timely, comparable, consistent, beneficial, and cost-effective in order to be beneficial for such users.

In today's world, in which global competition has intensified, the survival of businesses and their ability to gain a competitive advantage depends on providing factual, all-purpose, reliable, and comparable information. Reliable and comparable financial statements are only possible by employing a common accounting language. In Turkey, the standards developed for businesses of different sizes are currently applied in parallel to international regulations. It has also been decided that a financial reporting standard (FRS) for small- and microsized enterprises should be created to satisfy the bookkeeping limits. Additionally, they should not be subject to independent audits on the basis of their balances in order to ensure that their financial statements are fair, factual, and comparable.

Revenue (excluding the shareholders' contributions to capital) refers to all of the economic benefits obtained from the ordinary activities of a business during a certain period that generate an increase in equity (Akdoğan and Sevilengül, 2007, s. 566). According to previous FRSs (the TFRS 15, FRS for LMEs P5, and FRS for SMEs P7), revenue is an important income item that indicates a business's volume and size. It is also important to correctly determine the revenue and the period to which it belongs, since accounting errors and frauds can emerge. For this reason, businesses must make all transactions and the accounting of revenue all-purpose and comparable.

In Turkey, accounting and reporting of revenue are currently carried out within the scope of the Tax Procedure Laws (TPL)/ Accounting System Implementation General Communiqué (ASIGC), Turkish Accounting and Financial Reporting Standards (TFRS), and Financial Reporting Standards for Large and Medium-Sized Enterprises (FRS for LMEs). Moreover, the draft of the FRS for SMEs was published and presented to the public on July 12, 2019 by the Public Oversight, Accounting, and Auditing Standards Authority (KGK) to ensure that the financial statements of SMEs are comparable and factual. Specifically, this draft was prepared to ensure that the SMEs satisfy the bookkeeping limits and provide comparable, factual, and all-purpose financial information. Overall, it is important to present the financial statements of SMEs in a factual and all-purpose manner, since they play a significant role in the country's economy.

As for its details, the FRS for SMEs P7 deals with the rules for the sales of goods, service encounters, construction contracts (in which the business is the contractor), and the accounting of income obtained from interests, royalties, and dividends from the use of business assets by other parties. According to the FRS for SMEs P7, revenue is measured on the collected/ expected price after deducting the sales discounts within the scope of the agreement between the parties, and without separating the interest difference (FRS for SMEs 7.6). In other words, the FRS for SMEs P7 regulates the principles for the accounting of revenue from certain transactions and events.

However, it should be noted that there is a difference between legislation and standards regarding the determination of revenue, since an increase in the value of the monetary assets obtained from the ordinary activities of enterprises and revenue are important items that affect their financial statements. For example, in our tax legislation, the accounting of construction work income and expenses is recorded according to the completion method. The percentage of completion is then taken as a basis in the FRS for LMEs P5 and FRS for SMEs P7, and calculated in the same manner with the input method in the TFRS 15. Furthermore, profits and losses of income and expenses are recorded when the work is completed, while the revenue is calculated and recorded at the end of the period, regardless of the work completion year in the FRS for LMEs B5, FRS for SMEs P7, and TFRS 15. 
In sum, this study compared the FRS for SMEs P7 and existing financial reporting practices with the standards developed for businesses of different sizes in regard to the accounting of revenue. This accounting process was discussed within the scope of the FRS for SMEs P7, while specific issues were illustrated with examples. It is believed that the findings of this study will be useful to the literature and to parties interested in the accounting of revenue. 


\section{Giriş}

Küresel rekabetin yoğunlaştığı günümüz dünyasında, işletmelerin varlığını devam ettirebilmesi ve rekabet üstünlüğü sağlayabilmesi ihtiyaca uygun doğru bilgi sunmasına bağlıdır. Bu nedenle, işletmelerin muhasebe sistemi tarafından üretilen bilgilerin, finansal bilgi kullanıcılarının doğru karar alabilmelerini sağlayacak nitelikte sunulması gerekir. Mevcut durumda, Türkiye'de uluslararası düzenlemelere paralel olarak farklı ölçekteki işletmeler için geliştirilmiş standartlar uygulanmaktadır. Son olarak, bilanço esasına göre defter tutma hadlerini sağlayan ve bağımsız denetime tabi olmayan küçük ve mikro işletmeler için finansal raporlama standardı oluşturulmasına karar verilmiştir.

Türkiye'de hali hazırda küçük ve mikro işletmeler, faaliyetlerine ilişkin muhasebe kayıt ve işlemlerini vergi için muhasebe anlayışı ile Vergi Usul Kanunu/Muhasebe Sistemi Uygulama Genel Tebliği'ne (VUK/MSUGT) göre yapmaktadır (Kıymetli Şen ve Özbirecikli, 2020, s.2). KÜMİ FRS’nin yürürlüğe girmesi ile bilgi için muhasebe anlayışına geçiş için temel oluşturulması amaçlanmaktadır. Mevcut uygulamadaki standartlar ile karşılaştırıldığında uygulaması daha kolay ve daha az maliyetli olan KÜMİ FRS, tüm işletme faaliyetlerine ilişkin muhasebe işlem esaslarını kapsayan uygulanabilir bir finansal raporlama çerçevesi sunmaktadır. KÜMİ FRS’ye göre hazırlanan finansal tablolar işletme ile ilgilenen tarafların doğru kararlar almasına dayanak oluşturacaktır. KÜMİ FRS’nin uygulanmaya başlaması ile Avrupa Birliği (AB) ve diğer uluslararası düzenlemeler ile uyum sağlanması hedeflenmektedir (Kiymetli Şen ve Özbirecikli, 2020, s. 15). KÜMİ FRS'nin yürürlüğe girmesi ile en fazla etkinin Stoklar, Hasılat, Finansal Araçlar, Maddi ve Maddi Olmayan Duran Varlıklar, Finansal Durum Tablosu ve Kar veya Zarar Tablosu konularında olması beklenmektedir (Akbulut ve Can, 2020, s.91).

Hasılat, hissedarların sermayeye katkıları dışında, işletmenin dönem içerisindeki olağan faaliyetleri sonucunda elde edilen ve öz kaynaklarında artış meydana getiren ekonomik faydaların tamamıdır (Akdoğan ve Sevilengül, 2007, s.566). Standartlarda yer alan tanımlamalara göre hasılat, işletmelerin olağan faaliyet sürecinde meydana gelen gelirleridir (TFRS 15, BOBİ FRS 5.2, KÜMİ FRS 7.4). Hasılat işletmelerin iş hacmini ve büyüklüğünü gösteren önemli bir gelir kalemidir. İşletmeler açısından hasılatın doğru tespit edilmesi ve hasılatın ait olduğu dönemin belirlenmesi önemlidir.

Bu çalışmanın amacı, KÜMİ FRS Taslağı Bölüm 7 Hasılat düzenlemelerinin, Büyük ve Orta Boy İşletmeler için Finansal Raporlama Standardı (BOBİ FRS) Bölüm 5 Hasılat, Türkiye Finansal Raporlama Standartları (TFRS) 15 Müşteri Sözleşmelerinden Hasılat ve yürürlükteki mevzuat VUK/MSUGT hükümleri ile karşılaştırılması suretiyle incelemektir. Bu amaçla, hasılatın muhasebeleştirilmesi ve raporlanması hususu KÜMİ FRS B7 ile söz konusu düzenlemeler çerçevesinde mukayeseli olarak değerlendirilmiştir. Çalışmada, KÜMİ FRS B7 düzenlemesinde özellik arz eden konular örnekler yardımıyla açıklanmıştır.

\section{Literatür Taraması}

Literatürde hasılatın muhasebeleştirmesine ilişkin düzenlemeleri mukayeseli olarak inceleyen çalışmalar bulunmaktadır. Keskin ve Dinçer (2015) çalışmalarında, TFRS 15'in beş aşamalı modeline ilişkin temel özellikler ve gelirin tahakkuku üzerinde durmuşlar ve telekomünikasyon sektörüne ait bir örnekle TFRS 15 ile TMS 18 düzenlemelerinin temel farklarını ortaya koymuşlardır. Calayoğlu ve Yılmaz (2016) çalışmalarında, yazılım sektörünün önemli gelir unsurlarını TFRS 15'in beş aşamalı modeline göre açıklayarak, her bir gelir kaleminin hasılatını örnekler üzerinden tespit etmişlerdir. Aktaş ve Varol (2017) çalışmalarında, TFRS 15 ile TMS 18 standardının karşılaştırılmasını yapmışlar ve çok unsurlu sözleşmeler ve sözleşme değişiklikleri standartlar kapsamında örnek olay üzerinden incelemişlerdir. Ataman ve Cavlak (2017) çalışmalarında, TFRS 15 çerçevesinde hasılatın muhasebeleştirilmesine yönelik düzenlemeleri incelemişler ve bu düzenlemeler çerçevesinde bir uygulamaya yer vermişlerdir. Ataman ve Cavlak (2017) çalışmalarında, BOBİ FRS ile TMS/ TFRS mukayeseli olarak incelemişler ve inceleme konusu düzenlemelerin büyük ölçüde uyumlu olduğunu ancak bazı temel farklılıkların olduğunu tespit etmişlerdir. Gençoğlu (2017) çalışmasında, BOBİ FRS ile TMS/TFRS temel konular bağlamında benzerlikler ve farklılıkları ortaya koymuştur. Mert ve Baş (2017) çalışmalarında, TMS 18 kapsamında factoring işlemlerinde hasılat tutarının muhasebeleştirilmesi ve yeni uygulanacak olan UFRS 15 'in olası etkisi incelemişlerdir. Demirkol (2018) çalışmasında, TFRS 15'in beş aşamalı modelini örneklerle açıklamıştır. Doğan (2018) çalışmasında, BOBİ 
FRS ile VUK/MSUGT düzenlemelerini karşılaştırmalı olarak incelemiş, benzerlikler ve farklılıkları ortaya koymuştur. Gökçen, Öztürk ve Güleç (2018) çalışmalarında, BOBİ FRS ile TFRS setleri arasındaki farklılıklar incelemişler ve bu farklılıkların finansal raporlara etkisi üzerinde durmuşlardır. Kıllı ve Işık (2018) çalışmalarında, yıllara yaygın inşaat ve onarım işleri kapsamındaki müşterilerle yapılan inşa sözleşmelerini TFRS 15, BOBİ FRS ve TMS 23 standartları çerçevesinde örnek bir uygulama ile incelemişlerdir. Sabuncu (2018) çalışmasında, Tekdüzen Muhasebe Sistemi ve BOBİ FRS açısından hasılatın ölçümü ve muhasebeleştirilme esaslarını mukayeseli olarak incelemiştir. Çalış ve Hışman (2019) çalışmalarında, TFRS 15, BOBİ FRS B5 ve VUK çerçevesinde hasılatın muhasebeleştirilmesi hususunu karşılaştırmalı olarak incelemişler ve örnek bir uygulama ile konuyu ortaya koymaya çalışışlardır. Saban, Gürkan ve Vargün (2019) çalışmalarında, TFRS 15'in hasılatın zamanlaması hususunda ortaya koyduğu yaklaşımları gayrimenkul sektörü açısından örnek olay ile incelemişlerdir. Memiş (2019) çalışmasında, hasılatın muhasebeleştirilmesini MSUGT, TMS/TFRS ve BOBİ FRS düzenlemeleri çerçevesinde karşılaştırmalı olarak incelemiştir. Uyar Oğuz, Solmaz ve Ergün (2020) çalışmalarında, otel işletmelerinin hasılat kalemlerini, TFRS 15 kapsamında ele almışlar ve beş aşamalı edim sürecinin muhasebe kayıtlarını TFRS 15 ilkeleri doğrultusunda gerçekleştirmişlerdir.

Literatürde, KÜMİ FRS ile VUK/MSUGT, TMS/TFRS ve BOBİ FRS düzenlemeleri temel konular bağlamında mukayeseli olarak incelenmesini konu alan çalışmalar bulunmaktadır. Gökçen ve diğerleri (2019) çalışmalarında, KÜMİ FRS, BOBİ FRS ve TMS/TFRS temel konular bağlamında mukayese edilerek incelemişlerdir. Gençoğlu (2020) çalışmasında, KÜMI FRS, BOBİ FRS ve VUK/MSUGT karşılaştırarak incelemiş ve standartların ticari muhasebe anlayışııın yaygınlaşmasına katkı sağlayacağını ifade etmiştir. Akbulut ve Can (2020) çalışmalarında, KÜMİ FRS’nin temel özelliklerini, kapsadığı işletmeleri ve uygulanmaya başlamasının muhtemel etkilerini incelemişler ve KÜMİ FRS'nin daha nitelikli ve daha faydalı finansal bilgi sunan finansal raporlar hazırlamasına yardımcı olacağını ve vergi muhasebesi anlayışından bilgi muhasebesi anlayışına geçişte önemli bir adım olacağını ifade etmişlerdir. Kıymetli Şen ve Özbirecikli (2020), KÜMİ FRS, BOBİ FRS, TMS/TFRS ve VUK/MSUGT ile karşılaştırarak standartların iş dünyasına sağlayabileceği faydaları inceledikleri çalışmada, KÜMİ FRS'nin VUK/MSUGT'deki eksikleri tamamlama ve düşük maliyetli finansal bilgi sağlanmasına katkı sağlayacağını ifade etmişlerdir. Utku ve Kaya (2021) çalışmalarında, maddi duran varlıkların KÜMİ FRS, diğer standartlar ve muhasebe uygulamaları ile karşılaştırılarak benzerlikler ve farklılıklar ortaya koymuşlar, KÜMİ FRS kapsamında maddi duran varlıkların muhasebeleştirilmesini örneklerle göstermişlerdir. Sarısoy ve Eskin (2021), finansal raporlama standartlarının genel bir değerlendirmesini yaptıkları çalışmalarında, KÜMİ FRS’nin uygulamaya girmesi ile birlikte bilanço esasına göre muhasebe uygulamalarını yürüten tüm işletmelerde uluslararası standartların uygulanacağını ve bunun 'muhasebenin vergiden ziyade bilgi ihtiyacına hizmet etmesi' ilkesine katkı sağlayacağını belirtmişler ancak denetim sorununun çıkabileceğini vurgulamışlardır.

Literatürde, hasılatın muhasebeleştirilmesini TFRS 15, BOBİ FRS B5 ve VUK/MSUGT düzenlemeleri çerçevesinde ele alan çalışmalar bulunmaktadır. KÜMİ FRS düzenlemesini konu alan çalışmalarda ise düzenlemede yer alan bölümlerin mukayeseli olarak inceleyen, benzerlikler ve farklılıkları ortaya koymak üzere yapılıış çalışmalar bulunmaktadır. Hasılatın muhasebeleştirilmesini KÜMİ FRS B7 özelinde inceleyen çalışmaya rastlanmamıştır. Bu çalışmada, KÜMİ FRS B7 Hasılat standardı ile TFRS 15, BOBİ FRS B5 ve VUK/MSUGT düzenlemeleri karşılaştırılarak, benzerlikler ve farklılıklar ortaya koyulmaya çalışılmıştır. Çalışmanın bu yönü ile literatüre katkı sağlayacağı düşünülmektedir.

\section{KÜMİ FRS Bölüm 7 Hasılat}

Hasılat, bir işletmenin olağan faaliyetleri sonucunda ortaya çıkan, satış, faiz, kar payları, komisyon ve benzeri gelirleridir (Çalış ve Hışman, 2019, s.359). KÜMİ FRS B7'de hasılat, işletmenin olağan faaliyetleri esnasında ortaya çıkan gelirler olarak ifade edilmiştir. KÜMI FRS B7'nin kapsamı, mal satışı, hizmet sunumu, işletmenin yüklenici olduğu inşa sözleşmeleri ve işletme varlıklarının başkaları tarafından kullanılmasından sağlanan faiz, isim hakkı ve kâr payından oluşmaktadır. KÜMİ FRS B7'ye göre hasılatın, ülkemizdeki vergi uygulamalarında olduğu gibi, belirli gruplar arasında yapılan anlaşma çerçevesinde, satış iskontoları düşüldükten sonra, vade farkı ayrıştırılmaksızın doğrudan tahsil edilen veya edilmesi beklenen bedel üzerinden ölçülmesi esas alınmıştır. 
KÜMİ FRS B7'de, hizmet sunumu ve inşa sözleşmelerinin muhasebeleştirilmesinde; bir işlemin sonucunun güvenilir bir şekilde tahmin edilebildiği durumlarda, ilgili hasılat tutarı, raporlama dönemi sonu itibarıyla işlemin tamamlanma yüzdesi yöntemine göre finansal tablolara yansıtılır. Hizmet sunumu ve inşa sözleşmelerinde işin tamamlanan kısmına isabet eden hasilat beklenmeksizin dönemsel olarak finansal tablolara yansitılır.

\subsection{VUK/MSUGT-TFRS 15- BOBİ FRS B5 - KÜMİ FRS B7 Hasılat Taslağı Karşılaştırması}

Türkiye'de hasılatın muhasebeleştirilmesine ve raporlamasına ilişkin VUK/MSUGT ve Kamu Gözetimi Kurumu (KGK) tarafindan yayımlanan TFRS 15, BOBİ FRS B5 ile kamuoyunun görüşüne sunulan KÜMİ FRS B7 Hasılat düzenlemeleri hazırlanmıştır. İşletmelerin kapsamına girdikleri standart ile uyumlu muhasebeleştirme ve raporlama yapması zorunluluğu bulunmaktadır. Hasılatın muhasebeleştirilmesine ilişkin uygulamalar, KÜMİ FRS B7 ve Türkiye'deki mevcut uygulama ve standart uygulamaları kapsamında karşılaştırılmıştır.

\subsubsection{Hasılatın Ölçümü}

Hasılatın ölçümü ve muhasebeleştirilmesine ilişkin uygulamalar, Türkiye'deki mevcut uygulama ve standartlar kapsamında karşılaştırılmış ve Tablo 1'de gösterilmiştir.

VUK/MSUGT’a göre, mal ve hizmet satışına ilişkin hasılatın gerçekleşebilmesi için hasılat bedelinin içeriği ve tutarı açısından kesin değere ulaşması veya kesin değerini kazanması uygun ve yeterli koşul olarak kabul edilmektedir (Yıkılmaz, Deran ve Erduru, 2016, s.145). Hasılatın ölçümü, satış fiyatından satış iskontoları düşülerek yapılmaktadır (Doğan, 2018, s.120). VUK/MSUGT, mal veya hizmetin satılması ile sağlanan hasılatın faturalandırılması ile birlikte tahakkukunun gerçekleştirilmesi ve muhasebeleştirilmesi esasını benimsemiştir. Vadeli satışlarda vade farkları ve yabancı para cinsinden yapılan satışlarda dönem içinde ortaya çıkan kur farkları, brüt satışlar içerisinde kaydedilmekte ve peşin satışlar ile vadeli satışlar arasında bir ayrım yapılmamaktadır (Memiş, 2019, s.240). Vade farkının ilgili hesaplara yansıtılmaması özün önceliği kavramına aykırı bir uygulamadır (Çalış ve Hışman, 2019, s.374).

TFRS 15 hasılatın tanınması ve hesaplanmasında beş basamaklı bir model önermekte ve hasılatın muhasebeleştirilmesini, bazı edim yükümlülüklerinin ve şartlarının yerine getirilmesi şartına bağlamaktadır (TFRS 15.31). TFRS 15 hasılatın muhasebeleştirilmesini edim yükümlülüğünün yerine getirilmesi ile gerçekleştiriliyorken, muhasebeleştirilecek hasılat tutarının ölçümü edim yükümlülüğüne tekabül eden işlem bedeli ile yapılmaktadır.

BOBİ FRS B5, , işletmenin elde etmiş olduğu ekonomik faydaların işletmeye girmesinin muhtemel olması ve söz konusu faydaların güvenilir biçimde ölçülebilir olması durumunda hasılatın kayda alınmasını esas almıştır (BOBİ FRS 5.5). Hasılatın, mal veya hizmet satışına konu taraflar arasında yapılan sözleşme kapsamında, satış iskontoları düşüldükten sonra, satın alınan veya alınması muhtemel bedel esas alınarak ölçülmesi gerekir (BOBİ FRS 5.8). Hasılat bedelinde KDV gibi üçüncü kişilerden tahsil edilen veya edilecek bedeller hasılat tutarına eklenmez (BOBİ FRS 5.10). Acente ilişkisinde ise acente sadece komisyondan elde ettiği gelirini hasılat şeklinde kaydetmesi gerekmektedir (Ataman ve Gökçen, 2017, s.77). Hasılatın ilk kayda alınmasında, tahsilata ilişkin önemli bir risk bulunması durumunda tahsilat bedeli söz konusu riski yansıtacak şekilde düzeltilmesi ve hasılatın düzeltilmiş bedel üzerinden ölçülmesi esastır. Sonradan oluşan belirsizlik durumunda ise ilk kayda alınan hasılat tutarında bir düzeltme yapılmaz, hasılat karşılı̆̆ında kayda alınan alacak tutarı üzerinden değer düşüklüğü hesaplanır ve varsa değer düşüklüğü zararı muhasebeleştirilir (BOBİ FRS 5.11).

KÜMİ FRS B7'de, hasılat, taraflar arasında yapılan anlaşma kapsamında, satış iskontoları düşüldükten sonra, vade farkı ayrıştırılmaksızın doğrudan tahsil edilen veya edilmesi beklenen bedel üzerinden ölçülmektedir (KÜMİ FRS 7.5). KÜMİ FRS B7'de hasılatın kayda alınmasının şartı ekonomik faydaların işletmeye girmesinin muhtemel olması ve söz konusu faydaların güvenilir biçimde ölçülebilmesine bağlıdır. İşletmenin kendi adına sağlayabileceği brüt ekonomik fayda hasılatın kapsamını oluşturur ve üçüncü taraflar adına tahsil edilen tutarlar hasılat kapsamına girmez (KÜMİ FRS 7.6). Standart, VUK/MSUGT ile uyumlu olarak hasılatı doğrudan tahsil edilen veya edilmesi beklenen bedel tutar üzerinden kayda alınmasını esas almaktadır. Buna göre, hasılatın, vade farkı ayrımı olmaksızın alınan veya alınması beklenen nakit tutar 
üzerinden ölçülmesi öngörülmüştür. TFRS 15 ve BOBİ FRS B5 de ise 1 yıldan uzun vadeli satışlarda vade fark1 ayrıştırılmaktadır.

KÜMİ FRS B7'de, BOBİ FRS B5'e uyumlu olarak, üçüncü taraflar adına tahsil edilen katma değer vergisi (KDV) gibi tutarlar hasılat olarak değerlendirilmez ve finansal tablolara yansitılmaz (KÜMİ FRS 7.6, BOBİ FRS 5.10). Genellikle her bir işlem için ayrı ayrı uygulanan kayda alınma ölçütleri, bazı durumlarda işlemin özünü yansıtmak amacı ile tek bir işlemin ayrılabilir kısımlarına ayrı ayrı uygulanması gerekebilir (KÜMİ FRS 7.7).

KÜMİ FRS B7, BOBİ FRS B5 ve VUK/MSUGT’ne göre vadeli satışlarda, vade tarihi 1 yıldan az olması durumunda muhasebeleştirmesinde vade farkı ayrıştırılmadan tamamı hasılat olarak kayda alınır. TFRS 15'de ise böyle bir zorunluluk bulunmamaktadır. Vade farkı 1 yılı aşan satışlarda ise BOBİ FRS B5 ve TFRS 15'de vade farkı ayrıştırması yapılmaktadır. KÜMI FRS B7 ve MSUGT'de ise vade farkı 1 yılı aşsa bile vade farkı ayrıştırması yapılmamaktadır.

\subsubsection{Hizmet Sunumu ve İnşa Sözleşmeleri}

Hizmet sunumu ve inşa sözleşmelerine ilişkin uygulamalar, Türkiye'deki mevcut uygulama ve standartlar kapsamında karşılaştırılmış ve Tablo 2'de gösterilmiştir.

VUK/MSUGThükümlerinegöre,hizmetifaedildiğindegeliriçerikvetutarolarakkesinleştiğindemuhasebeleştirilebilmektedir (Kıymetli Şen ve Özbirecikli, 2018, s.467). İnşaat sözleşmeleri sonunda oluşan hasılat ve maliyetler inşaat sona erdiğinde tamamlanmış taahhüt yöntemi kullanılarak finansal tablolara yansıtılır. Buna göre yıllara yaygın inşaat ve onarım işlerinde işin bittiği yılda kesin kâr ya da zarar belirlenmekte ve tamamı o yılın geliri sayılmaktadır.

TFRS 15'e göre hizmet sunumu ve inşa sözleşmelerine ilişkin hasılatın muhasebeleştirilmesi için, edim yükümlülüğünün yerine getirilmesi ya da bir anda veya zamana yayılı bir şekilde kayda alınması ile finansal tablolara yansıtılmaktadır (TFRS 15 Prf. 35-38).

BOBİ FRS B5'de hizmet sunumu ve inşa sözleşmelerine ilişkin hasılat ve maliyetlerin, bir işlemin sonucunun güvenilir şekilde tahmin edilebildiği durumlarda, raporlama dönemi sonu itibarıyla hasılat tamamlanma yüzdesi yöntemine göre hesaplanarak dönemsel olarak finansal tablolara yansıtılacağı belirtilmektedir (BOBİ FRS 5.18). Bu yönteme göre, her raporlama dönemi sonunda tamamlanan işe isabet eden maliyet, hasılat ve kârın raporlanması sağlanır (BOBİ FRS 5.23). Hizmet sunumu ve inşa sözleşmesine ilişkin sonucun güvenilir olarak tahmin edilememesi durumunda geri kazanılması beklenen gider tutarı kadar hasılat muhasebeleştirilmekte ve ilgili işleme ilişkin herhangi bir kâr ortaya çıkmamaktadır (Sabuncu, 2018, s.241).

KÜMİ FRS B7'ye göre hizmet sunumu ve bir inşa sözleşmesinin sonucu güvenilir bir şekilde tahmin edileceği durumlarda hizmet veya sözleşmeye ilişkin hasılat ve maliyetlerin raporlama dönemi sonu itibarıyla işlemin tamamlanma düzeyi dikkate alınarak “Tamamlanma Yüzdesi Yöntemi” kullanılarak dönemsel olarak finansal raporlara alınacağı belirtilmektedir (KÜMİ FRS 7.14).

İnşaat işinin başladıktan sonra inşaatta ihtiyaç duyulan ilk madde ve malzemelerin alımında farklılık söz konusudur. İlk madde ve malzemelerin vadeli alımlarında ortaya çıkan vade farkı TFRS 15'e göre finansman gideri olarak kayıtlara alınırken, BOBİ FRS'de vade bir yıldan yüksek olduğu zaman finansman gideri niteliği taşır vade bir yılın altındaysa KÜMİ FRS ve VUK'ta olduğu gibi vade farkı maliyete dâhil edilir.

İnşaatla ilgili dönüştürme maliyetlerinde maliyet hesaplama yöntemi olarak VUK, KÜMİ FRS ve BOBİ FRS tam maliyet yöntemini kullanırken TFRS 15 normal maliyet yöntemini kullanır. Maliyet hesaplamadan BOBİ FRS her ne kadar tam maliyet yöntemini kullansa da normal maliyet yönteminin kullanımına da izin vermektedir.

Vergi mevzuatımızda inşaat işine ilişkin gelir ve giderlerin muhasebeleştirilmesi işin bitiminde yani tamamlanma yöntemi esas alınarak kayıtlara alınır. BOBİ FRS B5 ve KÜMİ FRS B7'den farklı olarak TFRS 15'de sözleşmenin tanımlanması 
üzerinde durulmuş ve beş basamaklı bir model ortaya koyulmuştur. TFRS 15'e göre hizmet sunumu ve inşa sözleşmelerine ilişkin hasılat tanımlanmış bir sözleşme ile edim yükümlülüğünün yerine getirilmesi ile ölçülmektedir. BOBİ FRS B5 ve KÜMİ FRS B7'de hizmet sunumu ve inşa sözleşmelerinde hasılat tamamlanma yüzdesi yöntemine göre hesaplanarak dönemsel olarak muhasebeleştirilmelidir (KÜMİ FRS 7.14; BOBİ FRS 5.18).

\subsubsection{Faiz, İsim Hakkı ve Kâr Payları}

Faiz, isim hakkı ve kâr paylarına ilişkin uygulamalar, Türkiye'deki mevcut uygulama ve standartlar kapsamında karşılaştırılmış ve Tablo 3'de gösterilmiştir.

VUK/MSUGT'ye göre vade farkı hasılattan ayrıştırılmadan muhasebeleştirilmektedir (Doğan, 2018, s.120). TFRS 15'de işletme faiz gelirlerini müşterileriyle yaptığı sözleşmelerden kaynaklanan hasılattan ayrı olarak muhasebeleştirir ve kapsamlı gelir tablosunda raporlar (TFRS 15 prf. 35). TFRS 15'e göre uygulama kolaylığı hariç olmak üzere tüm vade farkları ayrıştırılmaktadır (TFRS 15 prf. 60-63). Standartta, vade farkı etkin faiz yöntemine göre hesaplanarak hasılattan ayrıştırılmak suretiyle faiz geliri olarak kaydedilmekte ve finansal tablolarda sunulmaktadır (Memiş, 2019, s.242).

BOBİ FRS’ye göre, faiz, isim hakkı ve kâr payı gelirleri, hasılata ilişkin genel kayda alma ölçütlerini karşıladığında finansal tablolara yansitılır (BOBİ FRS 5.40). Faiz, etkin faiz yöntemine göre hesaplanarak muhasebeleştirilir, isim hakları, ilgili sözleşmenin özü dikkate alınarak sözleşme hükümleri çerçevesinde tahakkuk eder. Kar payları ise, hissedarların ödemeyi alma hakkı oluştuğu anda kayda alınır (BOBİ FRS 5.41). Etkin faiz yöntemine göre hesaplanan vade farkı tutarı faiz geliri olarak muhasebeleştirilir ve ilgili döneme kadar ertelenmiş faiz geliri olarak finansal durum tablosunda gösterilmektedir (BOBİ FRS 5.9). Buna göre, standart bir yıldan uzun vadeli alımlarda vade farkları ayrıştırılmasını öngörmektedir.

KÜMİ FRS B7'de isim olarak belirtilmemekle birlikte itfa edilmiş değer ile hesaplanması örneklendirilmektedir (KÜMi FRS 7.20). Ancak, aynı örnekte "etkin faiz oranı" yerine "iç verim oranı" ifadesi kullanılmıştır. Buna göre uygulama açısından, TFRS 15, BOBİ FRS B5 ve KÜMİ FRS B7 faiz hesaplaması açısından benzer niteliktedir (Gökçen, Öztürk ve Güleç, 2019:422).

\section{KÜMİ FRS Bölüm 7 Hasılatın Muhasebeleştirilmesine İlișkin Örnek Uygulamalar}

Çalışmanın bu bölümünde KÜMİ FRS B7'de yer alan düzenlemelerindeki tamamlanma yüzdesi yöntemi, vadeli satışlar ve satış sonrası hizmete ilişkin örnek uygulamalara yer verilecektir. Örnekler yazar tarafından oluşturulmuştur.

Örnek 1 (Tamamlanma Yüzdesi Yöntemi): A inşaat işletmesi, X inşaat projesi için 8.03 .2020 tarihinde müşteri işletme ile bir sözleşme imzalamıştır. İnşaatın toplam bedeli 4.000.000 $\square$ olarak belirlenmiştir. İnşaat 8.03.2021 tarihinde teslim edilecektir. İnşaatın öngörülen maliyeti 2.000.000 $\square$ 'dir. 31.12.2020 tarihinde katlanılan maliyet 1.400.000 $\square$ 'dir. KÜMİ FRS B7'de Tamamlanma yüzdesi yöntemine göre hasılatın hesaplanması aşağıdaki gibidir:

Tamamlanma Yüzdesi = Katlanılan maliyet $/$ Toplam öngörülen maliyet

Tamamlanma Yüzdesi $=1.400 .000 / 2.000 .000=\% 70$

Toplam proje bedeli $=4.000 .000$

KÜMİ FRS'ye göre;

2020 y1lı Has1lat Tutar $1=4.000 .000 * 0,70=2.800 .000$

KÜMİ FRS B7'de, hasılat tutarının hesaplanması ve muhasebeleştirilmesi TFRS 15 ve BOBİ FRS B5 uygulamaları ile uyumludur. 
170 Y1l. Yay. İnş. ve Onar. Mal.

350 Yillara Yay. İnş. Hakedişleri $\quad 2.800 .000$

600 Yurtiçi Satışlar

2.800 .000

31.12 .2020

600 Yurtiçi Satışlar

2.800 .000

690 Dönem Kârı/Zararı

2.800 .000

31.12 .2021

690 Dönem Kârı /Zararı

1.400 .000

622 Satılan Hizmet Maliyeti

1.400 .000

31.12.2020

690 Dönem Karı/Zararı

1.400 .000

692 Dönem Net Kâr/Zararı

1.400 .000

31.12 .2021

VUK/MSUGT’ye göre; 2020 yılı hasılatı iş bitmediği için hesaplanmamıştır.

Örnek 2 (Tamamlanma Yüzdesi Yöntemi): A inşaat taahhüt işletmesi 05.05.2020 tarihinde işyeri inşaatına başlamıştır. İnşaata ilişkin tahmini maliyet tutarı $500.000 \square$ ve taahhüt bedeli $750.000 \square$ 'dir.

31.12.2020 tarihinde hesaplanan inşaat maliyeti $300.000 \square$ 'dir.

Söz konusu veriler çerçevesinde BOBİ FRS B5, KÜMİ FRS B7 ve TFRS 15 Standartlarına göre dönem sonunda yapılacak hesaplamalar aşağıdaki gibidir;

Tamamlanma Düzeyi $=$ Katlanılan maliyet $/$ Toplam öngörülen maliyet $=300.000 / 500.000$

Tamamlanma Düzeyi $=\% 60$

Toplam Proje Bedeli $=750.000$

Bu hesaplamalar çerçevesinde 2020 yılı için kâr zarar tablosuna yansıtılacak hasılat tutarı;

Proje bedeli*ilerleme düzeyi $=750.000 * 0,60=50.000 \square$ 'dir.

KÜMI FRS B7'ye göre dönem sonunda hasılat hesaplanırken, MSUGT /VUK'ye göre dönem sonlarında hasılat hesaplanmayıp o döneme ait maliyetler bilanço kalemlerine aktarılır.

Örnek 3 (Vadeli Satışlar): A işletmesi 08.05.2021 tarihinde peşin satış fiyatı $800.000 \square$ olan X mamulünü 24 ay vade ile KDV hariç (\%18) $832.320 \square$ 'ye kredili olarak satmıştır. KDV tutarı peşin tahsil edilmiştir. Yıllık faiz oranı \%1'dir. 
KÜMİ FRS B7’ye göre muhasebeleştirmesi aşağıdaki gibidir.

08.05 .2021

100 Kasa $\quad 149.818$

220 Alıc1lar

832.320

600 Yurt İçi Satışlar

832.320

391 Hesaplanan KDV

149.818

31.12 .2021

120 Alıcilar

832.320

220 Alıcilar

832.320

08.05 .2022

102 Bankalar

832.320

120 Alıcilar

832.320

KÜMİ FRS B7 ve TDHP ise vade farkı ayrıştırması yapılmadan muhasebeleştirilir. Standart kapsamında, konsolidasyon ve ertelenmiş vergiler gibi hükümler yer almamaktadır (Akbulut ve Can, 2020, s.88). Vade tarihinin 1 yildan uzun olduğu vadeli satışlarda TFRS 15 ve BOBİ FRS B5'de vadeli satış tutarından ürünün bugünkü değeri bulunur ve aradaki fark ayrıştırılarak 382/482 Ertelenmiş Gelirler hesabında muhasebeleştirilir.

\section{BOBİ FRS ve TFRS 15'e göre;}

1. Y1l Faizi: $800.000 \square * 0,02=16.000$

2. Y1l Faizi: $816.000 \square *_{0,02}^{*}=16.320$

Toplam vade fark1 $=32.320$

08.05 .2021

100 Kasa

144.000

220 Alıcilar

832.320

600 Yurt İçi Satışlar

800.000

382 Ertelenmiş Gelirler

16.000

482 Ertelenmiş Gelirler

16.320

391 Hesaplanan KDV

144.000

31.12.2021

382 Ertelenmiş Gelirler

16.000

642 Faiz Gelirleri

16.000 
482 Ertelenmiş Gelirler

16.320

382 Ertelenmiş Gelirler

16.320

31.12 .2022

382 Ertelenmiş Gelirler

16.320

642 Faiz Gelirleri

16.320

31.12 .2022

120 Alıcılar

832.320

220 Alıcılar

832.320

08.05 .2022

102 Bankalar

832.320

120 Alıcilar

832.320

Örnek 4 (Satış Sonrası Hizmet): A işletmesi X işletmesine 10.04.2021 tarihinde KDV hariç (\%18) 500.000 $\square$ bedelle fotokopi makinasını peşin olarak satmıştır. Satış sözleşmesinde fotokopi makinasının 10.05.2022 tarihinde yapılacak 1 servis hizmet bedelinin satış bedeline dahil olduğu belirtilmiştir. TFRS 15, BOBİ FRS B5 ve KÜMİ FRS B7’ye göre muhasebeleştirmesi;

10.04 .2021

102 Bankalar

590.000

600 Yurt İçi Satışlar

490.000

480 Gelecek Aylara Ait Gelirler

10.000

391 Hesaplanan KDV

90.000

31.12 .2021

480 Gelecek Aylara Ait Gelirler

10.000

380 Gelecek Aylara Ait Gelirler

10.000

10.05.2021

380 Gelecek Aylara Ait Gelirler

10.000

600 Yurt İçi Satışlar

10.000

Muhasebe Enstitüsü Dergisi - Journal of Accounting Institute, 2021, 65: 75-89 
Makinenin alıcıya teslim edilmesi ile birlikte, makine satışı ile ilgili yükümlülük yerine getirilmiş ve buna ilişkin hasılat kayda alınmıştır. Satışa ilişkin servis hizmeti 1 yıl sonra yapılacaktır. Hizmet tutarı hasılat tutarından ayrıştırılarak muhasebeleştirilir. Dönem sonunda ilgili servis hizmeti uzun vadeli hesaptan kısa vadeli hesaba aktarılır. Servis hizmeti yerine getirildiğinde ise hasılat olarak kayda alınır. VUK/MSUGT’ye göre ise, satışın gerçekleştiği tarihte servis hizmetinin dâhil olduğu satış tutarının tamamı hasılat olarak muhasebeleştirilir.

\section{Sonuç ve Tartışma}

Günümüzde, işletmelerin rekabet üstünlüğü sağlaması ve uygun koşullarda ucuz finansman olanaklarına sahip olmasında standart bir muhasebe dili son derece önemlidir. Bu amaçla, KGK tarafından hazırlanan KÜMİ FRS, vergi muhasebesi anlayışından uzaklaşarak ticari muhasebe anlayışına geçme noktasında önemli bir adım olarak değerlendirilmektedir. Standardın, ülke ekonomisinde önemli bir yere sahip olan küçük ve mikro işletmelerin, muhasebeleştirme süreçlerinde kolaylaştırıcı uygulamalar içermesi, sade ve anlaşılır bir raporlama anlayışı benimsemesinin söz konusu işletmeler için standarda geçiş sürecinde olumlu katkı sağlayacağı düşünülmektedir.

Türkiye'de 2005 yılında farklı ölçekteki işletmeler için başlayan finansal raporlamada standartlaşma süreci KÜMİ FRS'nin uygulanmaya başlaması ile neredeyse bütün işletmeleri kapsayan duruma gelecektir. Diğer standartlara göre daha sade bir anlatıma sahip olan KÜMİ FRS’ye işletmelerin uyumunun daha hızlı olacağı düşünülmektedir. Türkiye'de küçük ve mikro işletmeler mevcut istihdamın önemli bir bölümünü karşılamakta ve ülke ekonomisine önemli katkılar sağlamaktadır. KÜMI FRS'nin yürürlüğe girmesi ve uygulanmaya başlaması ile birlikte küçük ve mikro işletmelerin daha nitelikli, daha faydal, ihtiyaca uygun ve karşılaştırılabilir finansal bilgi sunan finansal raporlar hazırlaması sağlanacaktır. Mevcut durumda finansal tablolarını VUK/MSUGT hükümleri çerçevesinde hazırlayan küçük ve mikro işletmelerin gerçeğe ve ihtiyaca uygun finansal rapor sunması, işletmelerin finansal bilgileri ile ilgilenen tüm bilgi kullanıcılarının, planlama ve karar süreçlerinde kullanabilecekleri doğru bilgilere ulaşmasını mümkün kılacaktır. Ülke ekonomisi açısından önemli bir yere sahip olan küçük ve mikro işletmelerin finansal verilerinin ekonomik anlamda aynı değeri ifade edebilmesi ve karşılaştırılabilirliliğin sağlanması açısından tek standardın uygulanması önem arz etmektedir.

Hasılatın tespiti konusunda mevzuat ve standartlar arasında farklılık söz konusudur. Vergi mevzuatında inşaat işine ilişkin gelir ve giderlerin muhasebeleştirilmesi işin bitiminde tamamlanma yöntemi esas alınarak gerçekleştirilir. BOBİ FRS B5 ve KÜMİ FRS B7'de tamamlanma yüzdesi esas alınır ve TFRS 15’teki girdi yöntemi ile aynı şekilde hesaplanmaktadır. Dolayısıyla, mevzuata göre tamamlanma yöntemine göre iş bitim döneminde kar ve zarar ortaya çıkarken, standartlara göre iş bitim yılına bakılmaksızın işin devam ettiği her dönemin sonunda hasılat hesaplanarak döneme ilişkin kar veya zarar kayıtlara alınır. Standartlarda, hasılatın muhasebeleştirilmesinde ekonomik faydanın işletmeye girmesi esası üzerinde durulmaktadır.

$\mathrm{Bu}$ çalışmada, hasılatın muhasebeleştirilmesi ve finansal raporlara yansıtılması hususunda ülkemizde hali hazırda uygulamada olan standartlar ile KGK tarafından hazırlanarak kamuoyunun görüşüne sunulan KÜMİ FRS seti taslağ1 Bölüm 7 Hasılat düzenlemesi karşılaştırılmış, benzerlikler ve farklılıklar tespit edilmiştir. KÜMİ FRS B7 diğer standartlar ile karşılaştıııldığında daha sade ve uygulayıcılar açısından anlaşılması kolay bir düzenlemedir. Hasılatın muhasebeleştirilmesine ilişkin uygulamaların genel olarak BOBİ FRS B5 ve TFRS 15'e uyumlu olduğu görülmektedir. Çalışmanın, KÜMİ FRS B7 kapsamında hasılatın muhasebeleştirilmesi ve raporlanması konusunda literatüre ve ilgi duyan taraflara yararlı olacağı düşünülmektedir.

Hakem Değerlendirmesi: Dış bağımsız.

Çıkar Çatışması: Yazar çıkar çatışması bildirmemiştir.

Finansal Destek: Yazar bu çalışma için finansal destek almadığını beyan etmiştir.

Peer-review: Externally peer-reviewed.

Conflict of Interest: The author has no conflict of interest to declare.

Grant Support: The author declared that this study has received no financial support. 


\section{Kaynaklar}

Akdoğan, N. ve Sevilengül, O. (2007). Türkiye muhasebe standartları ile uyumlu tekdüzen muhasebe sistemi uygulaması, Yenilenmiş ve Genişletilmiş 12. Baskı, Gazi Kitapevi, Ankara.

Akbulut, E. ve Can, M. E. (2020). Küçük ve mikro işletmeler için finansal raporlama standardı (KÜMİ FRS) taslağı hakkında. Muhasebe Enstitüsü Dergisi - Journal of Accounting Institute, 63, 85-93.

Aktaş, R. ve Varol, İ.D. (2017). Yeni hasılat standardı UFRS 15'e göre hasılatın muhasebeleştirilmesi: çok unsurlu sözleşmeler ve sözleşme değişiklikleri. Muhasebe ve Finansman Dergisi, (73): 28-50.

Ataman, B. ve Gökçen, G. (2017). Büyük ve orta boy işletmeler için finansal raporlama standardı (BOBİ FRS) uygulamaları. Beta Yayınc1lı, İstanbul.

Ataman, B. ve Cavlak, H. (2017). TFRS 15 Müşteri sözleşmelerinden hasılat: temel ilkelerin incelenmesi ve bir uygulama. Marmara Üniversitesi Íktisadi ve İdari Bilimler Dergisi, 39(2): 403-430.

Ataman, B. ve Cavlak, H. (2017). Büyük ve orta boy işletmeler için finansal raporlama standardı (BOBİ FRS) ile tam set Türkiye muhasebe ve Türkiye finansal raporlama standartlarının (TMS/TFRS) karşılaştırılması. Finans Ekonomi ve Sosyal Araştırmalar Dergisi, 2(3): 153-168.

Büyük ve orta boy işletmeler için finansal raporlama standardı (BOBİ FRS), 2021, KGK. EK 3.pdf (kgk.gov.tr) (Erişim Tarihi: 06.05.2021).

Calayoğlu, İ. ve Yılmaz, R. (2016). TFRS-15'e göre yazılım sektöründeki sözleşmelerin hasılatının hesaplanması ve tanınması. PESA International Journal of Social Studies, 2(2): 18-42.

Çalış, Y, Hışman, B. (2019). Hasılatın TFRS 15 müşteri sözleşmelerinden hasılat standardı, BOBİ FRS bölüm 5 ve vergi kanunlarına göre karşılaştırmalı incelenmesi. İstanbul Aydın Üniversitesi Dergisi. 11 (4) , 355-377.

Demirkol, Ö.F. TFRS 15 müşteri sözleşmelerinden hasılat standardı: 5 aşamalı model. AVRASYA Uluslararası Araştırmalar Dergisi, 6(15): 415-434, 2018.

Gençoğlu, Ü.G. (2017). Temel konularda BOBİ FRS ve TMS/TFRS karşılaştırması. Muhasebe ve Finansman Dergisi, (76): 1-23.

Doğan, A. (2018). Büyük ve orta boy işletmeler için finansal raporlama standardı ile VUK/MSUGT karşılaştırması. Muhasebe ve Finansman Dergisi, S.80, s.115-131.

Gençoğlu, Ü.G. (2020). Küçük ve mikro işletmeler için finansal raporlama standardı taslağı'nın BOBİ FRS ve vergi uygulamalarımız ile karşılaştırılması ve genel değerlendirme. Business and Economics Research Journal, 11(1), 187 -199.

Gökçen, G., Öztürk, E. ve Güleç, Ö. F. (2018). BOBİ FRS ve TFRS’nin finansal raporlara etkileri açsından karşılaştırılması. Finans Ekonomi ve Sosyal Araştırmalar Dergisi, 3(2): 437-457, 2018.

Gökçen, G., Öztürk, E. ve Güleç, Ö.F. (2019). KÜMİ FRS seti taslağı, BOBİ FRS seti ve tam set TMS/TFRS'nin temel konular açısından karşılaştırılması. Finans Ekonomi ve Sosyal Araştırmalar Dergisi, 4(3), 413-430.

Keskin, A.İ.ve Dinçer, B. UFRS 15-Müşteri Sözleşmelerinden Elde Edilen Hasılat Standardının İncelenmesi ve Telekomünikasyon Sektörüne İlişkin Bir Uygulama. Maliye ve Finans Yazıları, 1(103), 219-246, 2015.

Kıllı, M. ve Işık, Y. (2018). Yıllara yaygın inşaat ve onarım işlerinin TFRS 15 müşteri sözleşmelerinden hasılat standardı ve BOBİ FRS kapsamında incelenmesi. Anemon Muş Alparslan Üniversitesi Sosyal Bilimler Dergisi, 6 (6)

Kıymetli Şen, İ. ve Özbirecikli, M. (2020). KÜMİ FRS'nin iş dünyasına sağlayabileceği yararlar: BOBİ FRS, TMS/TFRS ve mevcut muhasebe sistemiyle mukayeseli bir inceleme. Muhasebe Bilim Dünyası Dergisi, S.22, ss.1-19.

Küçük ve Mikro İşletmeler İçin Finansal Raporlama Standardı Taslağı (KÜMİ FRS), 2019, KÜMİ FRS Taslak Metin.pdf (kgk.gov.tr) (Erişim Tarihi:07.05.2021).

Memiş, M.Ü. (2019). Hasılatın muhasebeleştirilmesinde MSUGT-TMS/TFRS-BOBİ FRS karşılaştırması. Kafkas Üniversitesi İktisadi ve İdari Bilimler Fakültesi Dergisi, C.10, S.19, s.214-235. 
Mert, H. ve Baş, E. (2017). TMS 18 hasılat ve UFRS 15 müşteri sözleşmelerinden hasılat standartlarının faktoring işletmeleri açısından değerlendirilmesi. Muhasebe ve Denetime Bakış Dergisi, 17(52): 35-56.

Utku, M. ve Kaya, Y. (2021). Küçük ve mikro işletmeler için finansal raporlama standartları (KÜMİ FRS) çerçevesinde maddi duran varlıkların muhasebeleştirilmesi. Mali Çözüm, 31(163), 123-139

Uyar Oğuz, H., Solmaz, S., A. ve Ergün, B. (2020). TFRS 15 müşteri sözleşmelerinden hasılat standardının otel işletmeleri açısından değerlendirilmesi. İşletme Araştırmaları Dergisi, 12 (2), 1489-1504.

Saban, M., Gürkan, S., Vargün, H. TFRS 15 Müşteri Sözleşmelerinden Hasılat Standardı: İnşaat Sözleşmeleri Üzerine Bir Uygulama. Muhasebe ve Vergi Uygulamaları Dergisi, 12(1): 43-64, 2019.

Sabuncu, B. (2018). Büyük ve Orta Boy İşletmeler İçin Finansal Raporlama Standardı ve Tekdüzen Muhasebe Sistemi Açısından Hasılatın Ölçüm ve Muhasebeleştirilmesinin İncelenmesi. Muhasebe Bilim Dünyası Dergisi, C.20, S.4, s.738-760.

Sarısoy, Ö. ve Eskin, İ. (2021). KOBİ IFRS'den günümüze finansal raporlama standartlarının genel bir değerlendirmesi. Muhasebe Enstitüsü Dergisi - Journal of Accounting Institute, S. 64, ss.19-37

Türkiye Finansal Raporlama Standardı (TFRS ) 15 Müşteri Sözleşmelerinden Hasılat, 2021, TFRS 15 Müşteri Sözleşmelerinden Hasılat (kgk.gov.tr). (Erişim Tarihi:06.05.2021).

Yıkılmaz, S., Deran, A. ve Erduru, İ. (2016). Hasılat yaratan işlemlerin muhasebeleştirilme ilkelerinin Türk vergi mevzuatı ve Türkiye muhasebe standartları kapsamında incelenmesi: muhasebe meslek mensupları üzerine bir araştırma. Ömer Halis Demir Üniversitesi IIBF Dergisi, 9(4):143-164. 


\begin{tabular}{|c|c|c|c|c|}
\hline İşlem & VUK/MSUGT & TFRS 15 & BOBİ FRS B5 & KÜMİ FRS B7 \\
\hline $\begin{array}{l}\text { Hasılatın Kayda } \\
\text { Alınması }\end{array}$ & $\begin{array}{l}\text { Satış faturasının hazır- } \\
\text { lanmasıly tahakkuk } \\
\text { etmekte ve muhasebe- } \\
\text { leştirilmektedir }\end{array}$ & $\begin{array}{l}\text { Edim yükümlülüğünün ye- } \\
\text { rine getirilmesi durumunda } \\
\text {.muhasebeleştirilmektedir }\end{array}$ & $\begin{array}{l}\text { Ekonomik faydanın işlet- } \\
\text { meye girme ihtimalinin } \\
\text { yüksek olması ve bu fayda- } \\
\text { ların güvenilir bir şekilde } \\
\text { ölçülebilir olması durumun- } \\
\text { da muhasebeleştirilmektedir }\end{array}$ & $\begin{array}{l}\text { Ekonomik faydanın işletme- } \\
\text { ye girme ihtimalinin yüksek } \\
\text { olması ve bu faydaların gü- } \\
\text { venilir bir şekilde ölçülebilir } \\
\text { olması durumunda muhasebe- } \\
\text { leştirilmektedir }\end{array}$ \\
\hline $\begin{array}{l}\text { Hasılatın Ölçüm } \\
\text { Yöntemi }\end{array}$ & Satış fiyatı-iskontolar & $\begin{array}{l}\text { Değişken bedel (İşlem be- } \\
\text { (deli esas alınarak ölçülür }\end{array}$ & $\begin{array}{l}\text { Satış iskontoları düşüldük- } \\
\text { ten sonra, alınan veya alın- } \\
\text { ması beklenen bedel esas } \\
\text { alınarak ölçülür }\end{array}$ & $\begin{array}{l}\text { Satış iskontoları düşüldükten } \\
\text { sonra, vade fark1 ayrıştırıl- } \\
\text { maksızın, doğrudan tahsil } \\
\text { edilen veya edilmesi beklenen } \\
\text { bedel üzerinden ölçülmektedir }\end{array}$ \\
\hline
\end{tabular}

\begin{tabular}{|l|c|c|c|c|}
\hline Tablo 2: Hizmet Sunumu ve İnşa Sözleşmeleri Karşılaştırması & BOBİ FRS B5 & KÜMİ FRS B7 \\
\hline İşlem & VUK/MSUGT & TFRS 15 & Edim yükümlülüğünün \\
Hizmet Sunumu & $\begin{array}{c}\text { Gelir içerik ve tutar } \\
\text { olarak kesinleştiğinde }\end{array}$ & $\begin{array}{c}\text { yerine getirilmesi ya da bir } \\
\text { anda veya zamana yayılı bir } \\
\text { şekilde }\end{array}$ & $\begin{array}{c}\text { Tamamlanma yüzdesi } \\
\text { yöntemi }\end{array}$ & $\begin{array}{c}\text { Tamamlanma yüzdesi } \\
\text { yöntemi }\end{array}$ \\
\hline İnşa Sözleşmeleri & $\begin{array}{c}\text { Tamamlanmış taahhüt } \\
\text { yöntemi }\end{array}$ & $\begin{array}{c}\text { Edim yerine getirildikçe } \\
\text { muhasebeleştirilir }\end{array}$ & $\begin{array}{c}\text { Tamamlanma yüzdesi } \\
\text { yöntemi }\end{array}$ & $\begin{array}{c}\text { Tamamlanma yüzdesi } \\
\text { yöntemi }\end{array}$ \\
\hline
\end{tabular}

\begin{tabular}{|l|c|c|c|c|}
\hline \multicolumn{7}{|l|}{ Tablo 3: Faiz, İsim Hakk1 ve Kâr Payları Karş1laştırması } \\
\hline İşlem & VUK/MSUGT & TFRS 15 & BOBİ FRS B5 & KÜMİ FRS B7 \\
\hline Vade Fark1 & Vade fark1 ayrıştırılmaz & $\begin{array}{c}\text { Bütün vade farkları ayrış- } \\
\text { tırılır }\end{array}$ & $\begin{array}{c}\text { Vade 1 yıldan uzunsa vade } \\
\text { fark1 ayrıştırılır }\end{array}$ & Vade fark1 ayrıştırılmaz \\
\hline Faiz & Belirlenmemiş & Etkin faiz yöntemi & Etkin faiz Yöntemi & İtfa edilmiş değer \\
\hline
\end{tabular}


